Proc. Estonian Acad. Sci. Biol. Ecol., 2005, 54, 3, 210-229

\title{
The effect of hydrodynamics on the phytoplankton primary production and species composition at the entrance to the Gulf of Finland (Baltic Sea) in July 1996
}

\author{
Inga Lips ${ }^{\text {a* }}$,Urmas Lips ${ }^{\mathrm{a}, \mathrm{b}}$, Kaisa Kononen ${ }^{\mathrm{c}, \mathrm{d}}$, and Andres Jaanus ${ }^{\mathrm{a}}$ \\ ${ }^{\text {a }}$ Estonian Marine Institute, University of Tartu, Mäealuse 10a, 12618 Tallinn, Estonia \\ b Present affiliation: Estonian Maritime Academy, Luise 1/3, 10142 Tallinn, Estonia; \\ urmas.lips@emara.ee \\ ${ }^{c}$ Finnish Institute of Marine Research, P.O. Box 33, FIN-00931, Helsinki, Finland \\ d Present affiliation: Academy of Sciences, Vilhonvuorenkatu 6, POB 99, FI-00501 Helsinki, \\ Finland; kaisa.kononen@aka.fi
}

Received 5 August 2004, in revised form 17 September 2004

\begin{abstract}
A 10-day multidisciplinary experiment with the aim to study the development of late summer phytoplankton bloom and the controlling hydrodynamic mechanisms was carried out at the entrance to the Gulf of Finland in July 1996. Clearly defined physical phenomena - a downwelling, near-slope jets, and a mesoscale anticyclonic eddy - were observed in the area during the study period. Due to the relatively strong currents connected to the jets and eddy periphery (current velocity up to $35 \mathrm{~cm} \mathrm{~s}^{-1}$ ), the advection of different water masses through the sampling area gave rise to a noteworthy variability of biological parameters. However, the formation of the eddy was reflected in horizontal patterns of the patchiness of phytoplankton productivity and species composition in the upper layer. The largest value of primary production was observed in the water mass trapped inside the anticyclonic eddy. The flagellates abundance was the highest inside the eddy, while the proportion of cyanobacteria in the plankton community was the largest outside. Our conclusion is that the vertical motions associated with the mesoscale eddy and occasional mixing events on the background of low concentrations of dissolved inorganic $\mathrm{N}$ and $\mathrm{P}$ created horizontally different conditions, which favoured simultaneous development of different groups of phytoplankton in a small spatial scale.
\end{abstract}

Key words: primary production, phytoplankton species composition, hydrodynamic control, Gulf of Finland.

*Corresponding author, inga@sea.ee 


\section{INTRODUCTION}

The knowledge about the physical processes controlling the distribution and productivity of phytoplankton in the sea has increased during the last decade (Franks, 1992, 1997; Talpsepp et al., 1994; Kononen et al., 1996). In the areas of inclined isopycnal surfaces, vertical movements of water masses and the associated nutrient fluxes from the deeper layers to the upper water layer can occur via different physical processes. These fluxes can increase primary production and under certain conditions can initiate algal blooms (Franks, 1992). Examples of enhanced production related to an anticyclonic eddy (Nelson et al., 1989), to an upwelling event (Talpsepp et al., 1994), and to frontal dynamics in combination with the wind induced-mixing (Kononen et al., 1996) have been described. Mechanisms for vertical nutrient transport related to mesoscale eddies (McGillcuddy \& Robinson, 1997; Oschlies, 2002; Martin \& Pondaven, 2003; McGillcuddy et al., 2003), including also sub-surface anticyclonic eddies (Martin \& Richards, 2001), have been discussed in recent papers.

The Gulf of Finland, located in the north-eastern part of the Baltic Sea (see Fig. 1), is an elongated estuarine basin with a complicated topography and coastline. Because of the large river input, the salinity and density of the gulf waters are lower than in the open Baltic. The entrance area to the Gulf of Finland is a region of interactions between the waters of the northern Baltic Proper and the gulf. According to the classical long-term circulation scheme the saltier water from the northern Baltic Proper intrudes the gulf along the Estonian coast and the less saline water flows out from the gulf along the Finnish coast. The convergent inflowing and outflowing waters of different salinity form a quasi-permanent front at the entrance area (Pavelson et al., 1997). Due to the varying wind forcing and complicated topography, mesoscale physical phenomena - upwelling/downwelling, eddies, and current jets - can often be observed in the area.

Earlier studies carried out in the same area during the late summer phytoplankton blooms have revealed a significant influence of hydrophysical processes onto the bloom development. It was proposed that the mesoscale blooms of Aphanizomenon flos-aquae (Linné) Ralfs (taxonomy under revision) benefit from the nutrient-pulsing events, which could be caused by the wind-induced vertical mixing (Kononen et al., 1996). A good correlation between the spatial distribution of the bloom-forming species and water mass characteristics in the frontal area was detected (Moisander et al., 1997). The horizontal advection was found to be the main source of temporal variation of chlorophyll $a$ concentration in the decaying phase of an intense bloom event of cyanobacteria (Kononen et al., 1998).

A 10-day multidisciplinary experiment at the entrance to the Gulf of Finland was carried out in July 1996. The aim of the study was to investigate the development of the late summer phytoplankton bloom and the controlling hydrodynamic mechanisms. The phytoplankton community was dominated by the dinoflagellate 
Heterocapsa triquetra Ehrenberg and the cyanobacterium Aphanizomenon flosaquae during the study period (Kononen et al., 1999). The intensive mesoscale hydrodynamic activity led to the advection of water masses of different origin through the sampling area and to the downward and upward movements of water parcels related to a downwelling, jet currents, and an anticyclonic eddy (Pavelson et al., 1999; Laanemets et al., 2005).

The main aim of the present paper is to estimate the influence of the mesoscale hydrodynamic processes and wind-induced vertical mixing onto the productivity and community structure of phytoplankton. Mostly the data collected at five sampling stations positioned at different sites relative to the location of the observed mesoscale phenomena are used.

\section{MATERIAL AND METHODS}

Materials

The biological measurements supplemented by conductivity-temperaturedepth (CTD) casts were carried out daily at five stations - A1, A2, A3, and A4 (conducted from the $\mathrm{r} / \mathrm{v}$ Reet, Estonian Marine Institute) and C (conducted from the r/v Aranda, Finnish Institute of Marine Research) - from 18 to 26 July 1996 (Fig. 1). The location of the stations $\left(\mathrm{C}-59^{\circ} 17^{\prime} \mathrm{N}, 22^{\circ} 33^{\prime} \mathrm{E}\right.$; A1 $-59^{\circ} 15^{\prime} \mathrm{N}$, $22^{\circ} 36^{\prime} \mathrm{E}$; $\mathrm{A} 2-59^{\circ} 15^{\prime} \mathrm{N}, 22^{\circ} 30^{\prime} \mathrm{E}$; A3 $-59^{\circ} 19^{\prime} \mathrm{N}, 22^{\circ} 30^{\prime} \mathrm{E}$, and $\mathrm{A} 4-59^{\circ} 19^{\prime} \mathrm{N}$, $22^{\circ} 36^{\prime}$ E) was defined according to the results of a pilot survey on 15-16 July to cover the near-slope downwelling area - one station in the centre and the others surrounding it at a distance of ca $5 \mathrm{~km}$.

The pooled samples were prepared at all stations to represent the upper mixed layer (UML). The water samples were collected at $1.5-\mathrm{m}$ intervals (using $1.7 \mathrm{~L}$ Niskin water samplers) from the surface down to the seasonal thermocline, the depth of which was determined from the CTD casts. The samples from discrete depths were mixed and divided into sub-samples for analyses of size-fractionated chlorophyll $a(\mathrm{Chl} a)$ potential primary production (PP), phytoplankton biomass, and species composition. At the beginning of the study, the pooled samples represented the upper 30-m water layer (with some deviations), but later the UML depth was less than $15 \mathrm{~m}$, and the pooled samples correspondingly represented fewer sampling depths.

Meteorological parameters were recorded by the $\mathrm{r} / \mathrm{v}$ Aranda weather station. Two moorings with two current meters at depths of 12 and $35 \mathrm{~m}$ were deployed at stations $\mathrm{C}$ and $\mathrm{A} 3$ for the whole study period. Seven nutrient samples were collected daily at every station - one sample above the thermocline, one sample below it, and the remaining five within the thermocline layer with 2.5 -m intervals. A more extensive daily sampling of nutrients (ca 14 samples) was conducted at station $\mathrm{C}$. 


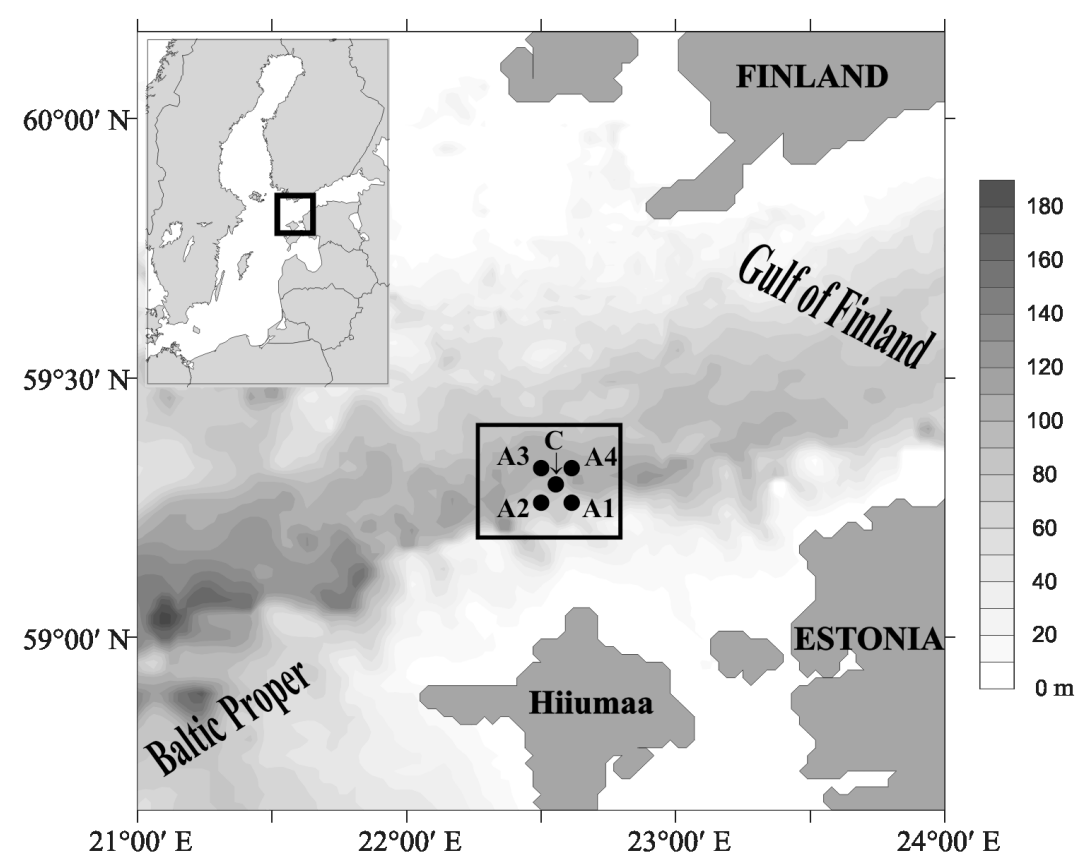

Fig. 1. Map of the study area and location of stations.

The development of the hydrophysical fields in the study area was followed by the night-time mesoscale surveys consisting of 3-6 north-south oriented 1017-km long transects $4.6 \mathrm{~km}$ apart on board the $\mathrm{r} / \mathrm{v}$ Aranda. A towed undulating system carrying a NBIS Mark III CTD profiler and Electro-Optic Suarez fluorometer was used. Simultaneous current measurements using a ship-board Acoustic Doppler Current Profiler (ADCP) were carried out.

\section{Methods}

The CTD measurements were carried out using a NBIS Mark III probe (on board the r/v Reet) and SeaBird 911Plus profiler (on board the r/v Aranda). Intercalibration of CTD probes was performed and the salinity values were corrected on the basis of water sample analyses by a high precision salinometer AUTOSAL (Guildline). Currents at the moorings were measured by using AANDERAA recording current meters RCM-7, RCM-6, and RCM-4 with a time step of $10 \mathrm{~min}$. The measurement and data processing methods for the mesoscale CTD/fluorometer and ADCP mapping are presented in detail by Laanemets et al. (2005) and Pavelson et al. (1999). 
Dissolved inorganic nutrients $\left(\mathrm{PO}_{4}-\mathrm{P}, \mathrm{NO}_{3}-\mathrm{N}, \mathrm{NO}_{2}-\mathrm{N}\right)$ were determined according to the guidelines for the third stage of the Baltic monitoring program (HELCOM, 1988a). Samples taken at station C were analysed immediately after sampling on board the $\mathrm{r} / \mathrm{v}$ Aranda. Samples collected at the other stations were delivered to the onshore laboratory in Kärdla (Hiiumaa) daily and analysed within 24-30 h.

Samples for quantifying phytoplankton species $(300 \mathrm{~mL})$ were preserved with acidic Lugol's solution. Cyanobacterial filaments were counted as $100-\mu \mathrm{m}$ segments and other phytoplankton species as single cells or colonies by the Utermöhl (1958) technique. For biomass calculation the tables of cell volume were used (Edler, 1979; Kononen et al., 1983).

The estimates of PP were based on sub-samples of the pooled water sample. The PP capacity was measured by adding $2 \mu \mathrm{Ci} \mathrm{NaH}{ }^{14} \mathrm{CO}_{3}$ to three parallel $30-\mathrm{mL}$ aliquots of the pooled sample. Samples were incubated in the deck incubator under subsurface $(5-10 \mathrm{~cm})$ light $(100 \%)$ and two $30-\mathrm{mL}$ aliquots were incubated in the dark. Radioactivity was measured in the total sample after addition of $1 \mathrm{M} \mathrm{HCl}$ (particulate production and exudates). Incorporated ${ }^{14} \mathrm{C}$ was assayed with a liquid scintillation counter (1217 RackBeta, Wallac LKB for stations A1, A2, A3, and A4; 1219 RackBeta, Wallac LKB for station C). For the calculation of PP, the dark value was subtracted from the mean of the light values. The PP was calculated using the BMB guideline (Nielsen \& Bresta, 1984).

To get the concentration of Chl $a$ the pooled sample was poured through a $20-\mu \mathrm{m}$ mesh. The Chl $a$ concentration in the $<20-\mu \mathrm{m}$ fraction and in the unfractionated sample was determined on Whatman GF/F glass-fibre filters following the extraction at room temperature in the dark with $96 \%$ ethanol for $24 \mathrm{~h}$. The concentration was measured fluorometrically (Perkin, Elmer LS-2B) (HELCOM, 1988b).

\section{RESULTS}

\section{Meteorological and hydrographical background}

The early summer was exceptionally cold and rainy in the Baltic Sea region in 1996. As a result, the surface water temperature was mainly below $14^{\circ} \mathrm{C}$ in the study area at the beginning of the study in mid-July. However, during the study period, the surface water mean temperature at the stations of biological measurements rose from 13.5 to $15.5^{\circ} \mathrm{C}$ (see Fig. 2a). The wind pattern was characterized by northwesterly winds (direction changed from west to north-east) of variable speed (from 2 to $13 \mathrm{~m} \mathrm{~s}^{-1}$ ). West and north-west wind impulses with the wind speed of up to $13 \mathrm{~m} \mathrm{~s}^{-1}$ and duration of about half a day were observed on 15 and 16 July in both cases. Additional moderate wind impulses of up to $9 \mathrm{~m} \mathrm{~s}^{-1}$ appeared on 21 and 22 July (wind blowing from north) and on 25 July (wind blowing from west), 
while the wind speed was less than $6 \mathrm{~m} \mathrm{~s}^{-1}$ during the rest of the study period. The surface water mean salinity at the stations of biological measurements varied between 6.4 and 6.7 (Fig. 2a). In general, the northern Baltic Proper waters, which occupied the surface layer in the observation area at the beginning of the study, were replaced by fresher waters of the Gulf of Finland on 20 July. Although the
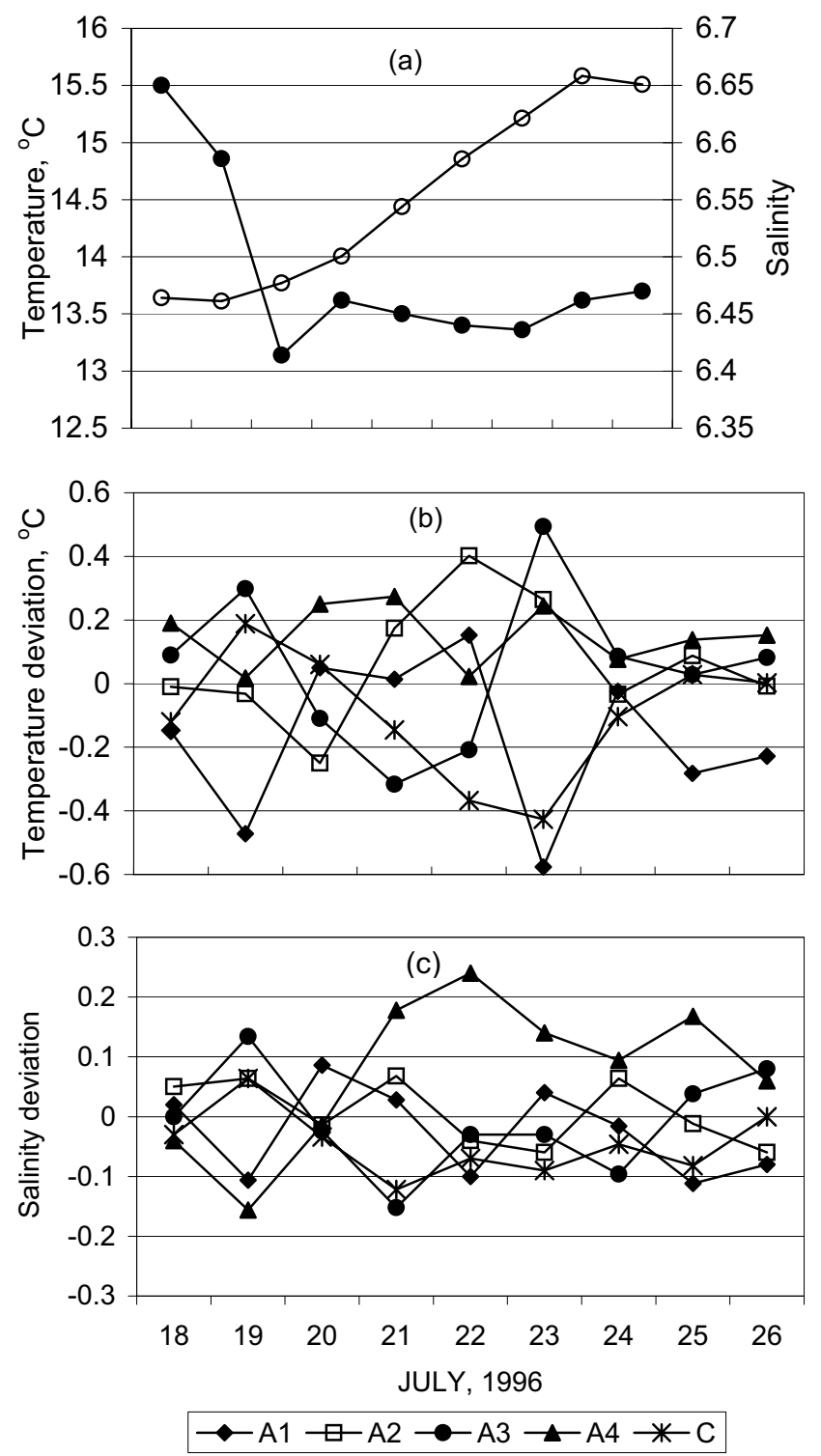

Fig. 2. Daily mean surface water temperature and salinity (a), and deviations from the mean temperature (b) and salinity (c) at the sampling stations on 18-26 July 1996. 
spatio-temporal variations of salinity exceeded 0.3 , the strong quasi-permanent salinity (and density) front, usually expected to dominate at the entrance to the Gulf of Finland, was not the most important manifestation of the water dynamics in the vicinity of the sampling stations in our case.

\section{Mesoscale phenomena}

Clearly defined mesoscale physical phenomena were observed in the area under investigation during the study period. Two successive wind impulses on 15 and 16 July caused a downwelling and strong eastward current along the steep coastal slope. The current velocities in the jet exceeded $30 \mathrm{~cm} \mathrm{~s}^{-1}$ resulting in a daily mean transport of $20 \mathrm{~km}$ at a depth of $35 \mathrm{~m}$ (see Fig. 3, station A3, 18-19 July). After the weakening of the wind on 18 July, the downwelling vanished. An anticyclonic eddy with a diameter of $\sim 20 \mathrm{~km}$ was formed in the eastern survey area on 20-21 July. The eddy, with velocities of $30-35 \mathrm{~cm} \mathrm{~s}^{-1}$ in its periphery in the upper $60 \mathrm{~m}$ layer, migrated slowly northward until the end of the experiment (Pavelson et al., 1999).

The relative location of stations for biological sampling in respect to the spatial occurrence of the hydrophysical events was different (see Fig. 4). The

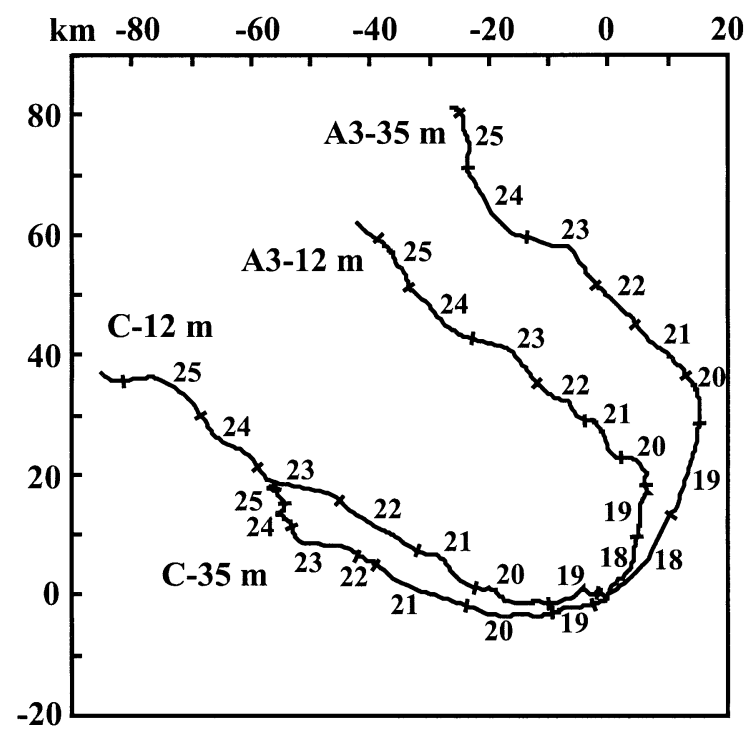

Fig. 3. Progressive vector diagram of currents at mooring stations $A 3$ and $C$ at depths of 35 and $12 \mathrm{~m}$. The numbers between the ticks indicate the dates in July. Distances from the starting point (0.0) in kilometres to the north and to the east are shown on the axes. Starting date and time are 18 July 5 a.m. for mooring A3 and 18 July 1 p.m. for mooring C. 

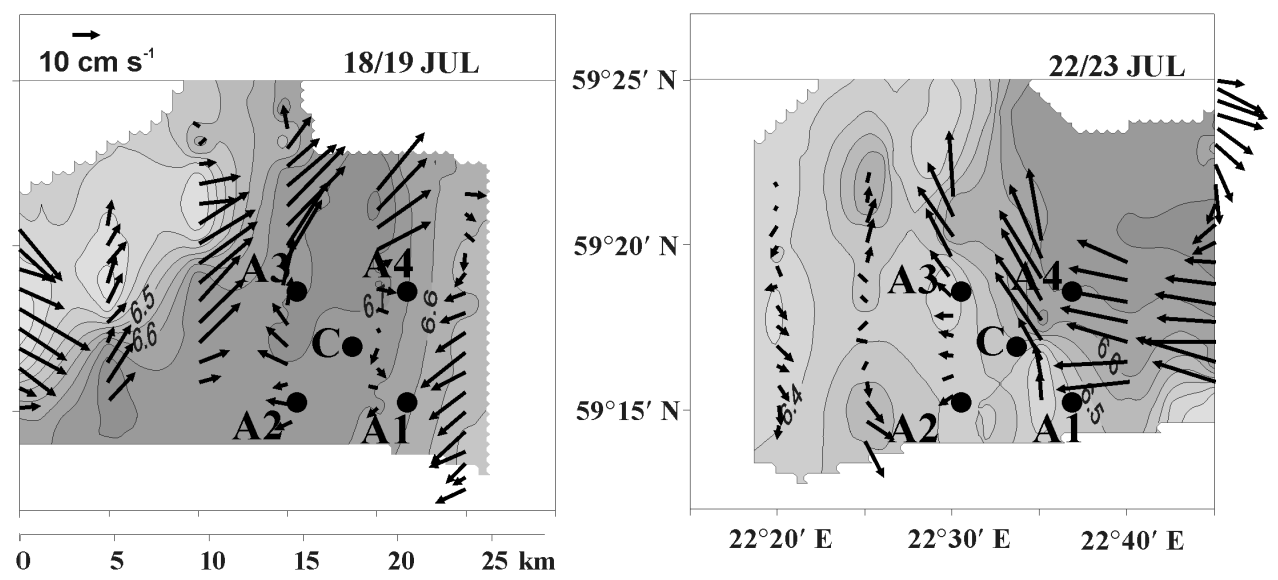

Fig. 4. Salinity distribution at 5-m depth overlaid with the current vectors (scale given in the lefthand panel) from the shipboard ADCP at 12-m depth during two night-time surveys on 18/19 July and on 22/23 July (figure redrawn from Pavelson et al., 1999). The location of sampling stations in relation to the observed mesoscale features is shown.

downwelling event included all five stations, but only station A3 was under the direct influence of the associated jet current. Station A4 was located inside the eddy since its formation on 21 July until the end of the study period. This is confirmed by observations of the surface water salinity, which was on average 0.17 higher at station A4 than the mean salinity at other stations on 21-26 July (Fig. 2c). At the same time there were no evident differences in the temperature deviations (Fig. 2b). Station A2 remained outside the area influenced by the eddy for the whole study period. Stations A1, A3, and C were located in the eddy periphery or even a little outside, where high current velocities were observed. It could be interpreted that starting from 22 July a strong north-west directed jet (to the south of the anticyclonic eddy) flowed through the study area (Kononen et al., 1999). The daily horizontal distance covered by a water parcel in the surface layer at stations $\mathrm{C}$ and $\mathrm{A} 3$ is estimated on the basis of current measurements to vary from 8 to $15 \mathrm{~km}$, with some higher velocities at station C (Fig. 3). Thus, a quick change of water masses could be expected at these stations.

\section{Stratification}

The vertical stratification of the water column was quite complicated and variable in the study area. At the beginning of the measurement campaign, due to the downwelling, the upper mixed layer (UML) was very deep (25-30 m). 
The UML was underlain by a layer with relatively small vertical gradients of temperature, salinity, and density down to the 50-60 m depth and, below that, an almost coinciding thermocline and halocline were observed (Fig. 5a). With the start of the downwelling relaxation, the thermocline rose up and the thickness of both the UML and the layer of low gradients decreased. During the last three days, the water column stratification obtained a step-like structure. The UML (with a thickness of about $10 \mathrm{~m}$ ) and the other layers of small vertical gradients were separated by the upper thermocline (at depths of 10-15 m), the lower thermocline $(25-35 \mathrm{~m}$ ), and the halocline (around $60 \mathrm{~m}$; Fig. 5b). The appearance of the upper thermocline and a decrease of the UML thickness to less than $15 \mathrm{~m}$ at the end of the study period were generated by the solar heating and wind speed smaller than in the period just before the start of the observations. The vertical structure of the water column inside the observed anticyclonic eddy differed from the surrounding waters (Fig. 5c, d). The larger temperature and salinity values in the layer between 10 and $40 \mathrm{~m}$ were similar to the values for the downwelling event and the vertical density gradient in the 10-60-m layer was much smaller than in the surrounding waters. For instance, on 22 July, the gradient was only

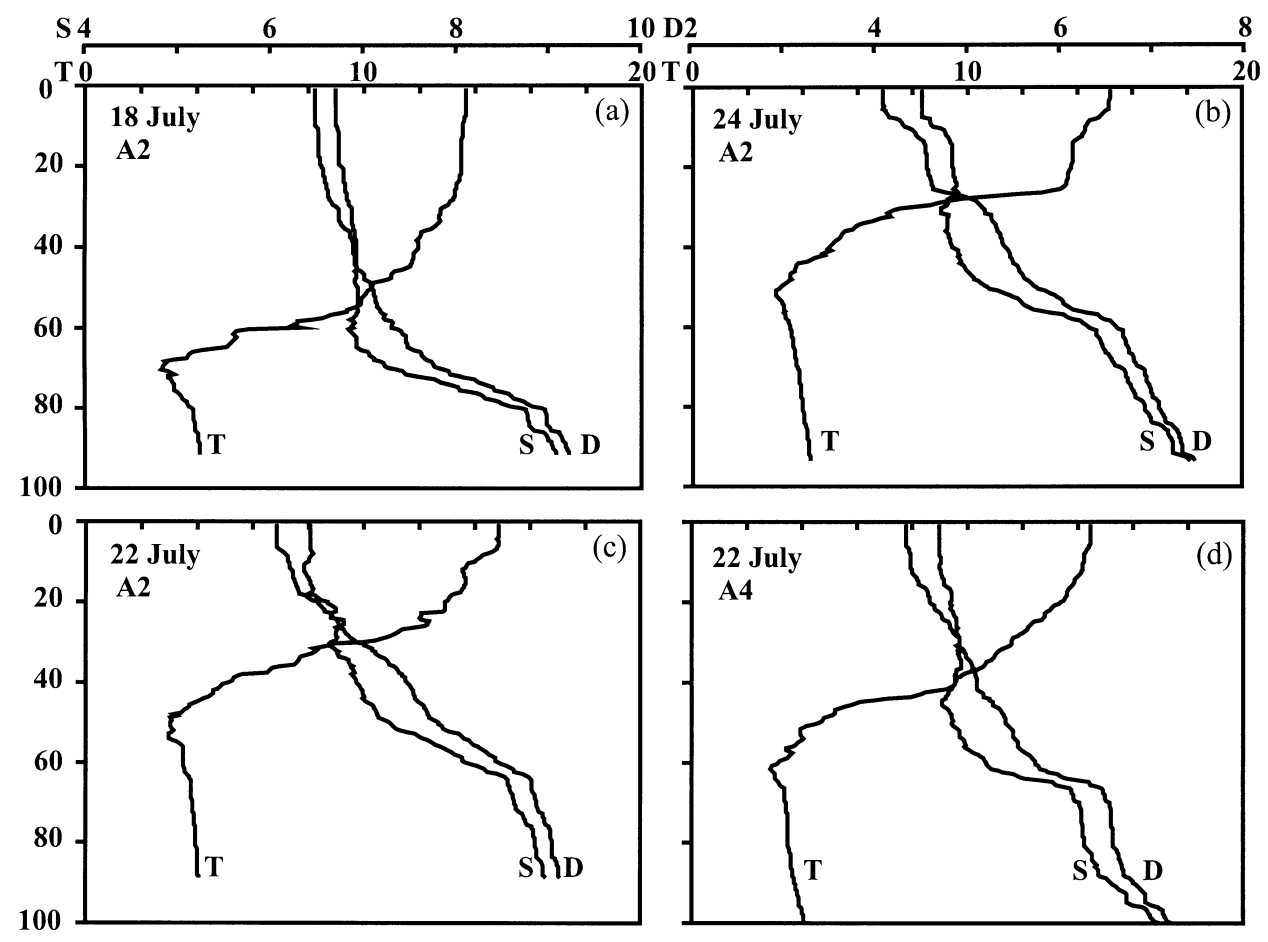

Fig. 5. Vertical profiles of temperature $\left(\mathrm{T}\right.$ in $\left.{ }^{\circ} \mathrm{C}\right)$, salinity (S), and density anomaly (D in $\left.\mathrm{kg} \mathrm{m}^{-3}\right)$ in the depth range 0-100 $\mathrm{m}$ at station A2 (18 July, 24 July, and 22 July) and at station A4 (22 July). 
$0.027 \mathrm{~kg} \mathrm{~m}^{-4}$ at station $\mathrm{A} 4$ and $0.054 \mathrm{~kg} \mathrm{~m}^{-4}$ at station A2. In addition, the isopycnal surfaces in the upper layer revealed some inclination - the isopycn of $1.0044 \mathrm{~kg} \mathrm{~m}^{-3}$ surfaced at station A4 and lied below $15 \mathrm{~m}$ at station A2 outside the eddy (example taken on 22 July).

\section{Nutrients}

The upper layer was depleted of inorganic nitrogen and phosphorus in the study area. The measured concentrations $-0.01-0.03 \mu \mathrm{M}$ of $\mathrm{PO}_{4}-\mathrm{P}$ and $<0.05 \mu \mathrm{M}$ of $\left(\mathrm{NO}_{2}+\mathrm{NO}_{3}\right)-\mathrm{N}$ - were mostly close to the detection limits. Larger values of dissolved inorganic nitrogen (DIN) and dissolved inorganic phosphorus (DIP) concentrations were measured in the deeper layers below the thermocline, and the DIN : DIP molar ratio in this layer was mostly less than 5 . The nutricline depth, defined as the depth where $\mathrm{PO}_{4}-\mathrm{P}$ and/or $\left(\mathrm{NO}_{2}+\mathrm{NO}_{3}\right)-\mathrm{N}$ concentrations rose to 0.05 and $0.1 \mu \mathrm{M}$, respectively, was estimated to be $40-45 \mathrm{~m}$ during the two first days of the study. Later the nutricline depth varied between 25 and $35 \mathrm{~m}$ at the stations outside the eddy and between 20 and $40 \mathrm{~m}$ at station A4.

\section{Chlorophyll $a$}

Chlorophyll $a$ concentrations measured in the pooled sample from the UML were between 1.9 and $5.3 \mathrm{mg} \mathrm{m}^{-3}$. This range of values is usual for the summer period in the open Gulf of Finland. The mean Chl $a$ concentration decreased in the study area during the first three days (Fig. 6a). After 20 July, a continuous increase of Chl $a$ concentration was observed. Chl $a$ was found mainly in the $<20-\mu \mathrm{m}$ size fraction, and the temporal changes in this size fraction were similar to the changes of total Chl $a$ content (Fig. 6a). Chl $a$ concentration in the $<20-\mu \mathrm{m}$ size fraction was $1.4-4.5 \mathrm{mg} \mathrm{m}^{-3}$. The mean concentration of Chl $a$ in the $>20-\mu \mathrm{m}$ size fraction increased during the study period, being about $0.5 \mathrm{mg} \mathrm{m}^{-3}$ during the first days and about $1.0 \mathrm{mg} \mathrm{m}^{-3}$ during the last days of the experiment (Fig. 6a). The characteristic pattern of spatio-temporal variation of the total Chl $a$ concentration was as follows. The stations where a little higher values were measured during the downwelling event (stations A2 and A3) revealed lower $\mathrm{Chl} a$ values under the influence of the mesoscale eddy (Fig. 6b). In contrast, the concentration at station A4 was lower than at other stations during the first three days and higher than at other stations after the eddy had formed.

It is noteworthy that the size fractions behaved differently at station A4 (situated inside the eddy) and at station A2. The Chl $a$ concentration exceeded the mean in the $>20 \mu \mathrm{m}$ size fraction and was lower than the mean in the $<20-\mu \mathrm{m}$ size fraction at station A2, while it was lower than the mean in the $>20-\mu \mathrm{m}$ size fraction 

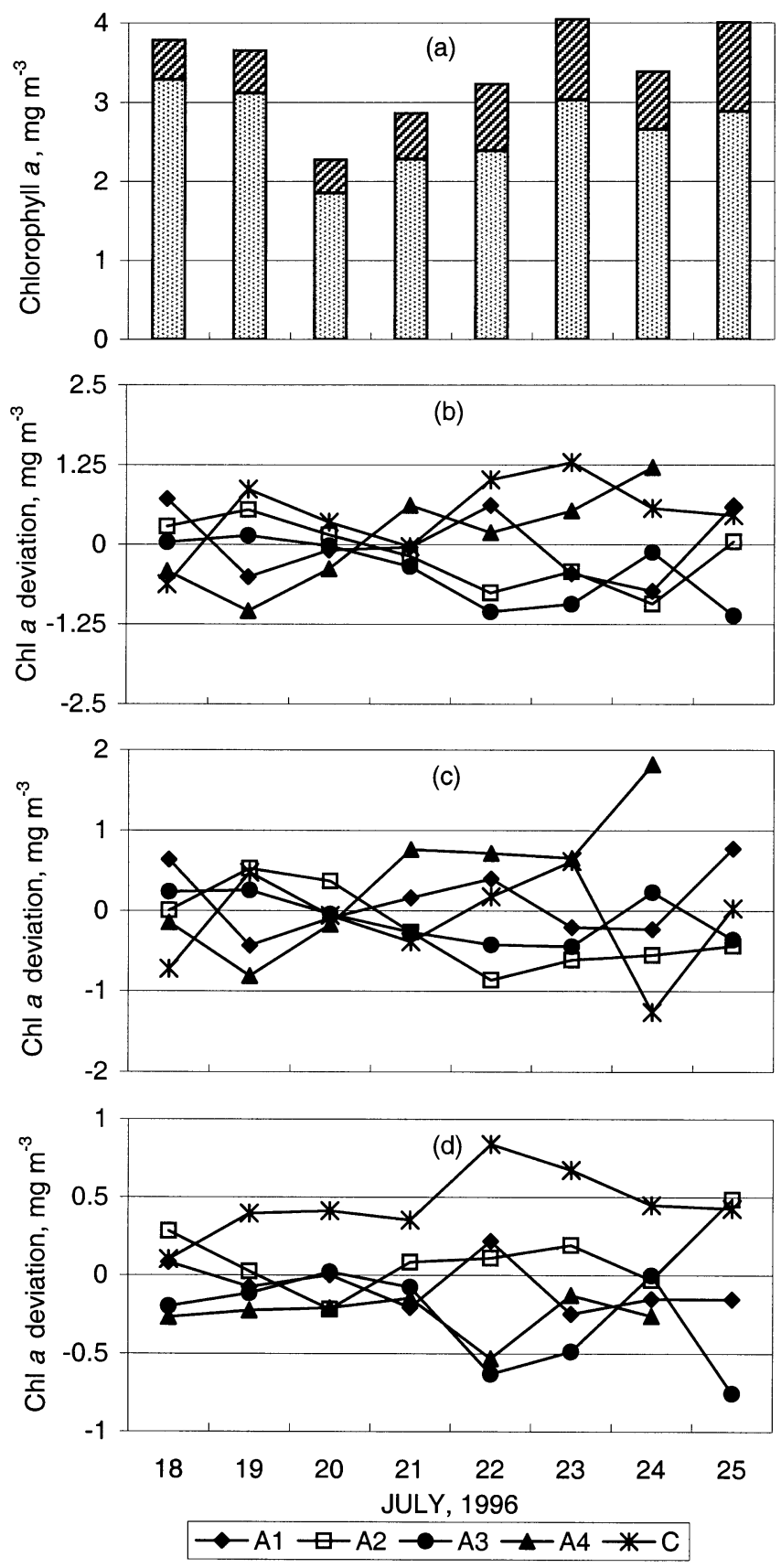

Fig. 6. Daily mean Chl $a$ concentration (a; bars, striped area $->20-\mu \mathrm{m}$ fraction and dotted area $<20-\mu \mathrm{m}$ fraction) and Chl $a$ deviations in different size fractions $(\mathrm{b}-$ total, $\mathrm{c}-<20 \mu \mathrm{m}$, and $\mathrm{d}->20 \mu \mathrm{m})$ at the sampling stations on 18-26 July 1996. 
and exceeded the mean in the $<20-\mu \mathrm{m}$ size fraction at station A4 (Fig. 6c, d). The highest values of Chl $a$ concentration in the $>20-\mu \mathrm{m}$ size fraction were measured at station C on 22 and 23 July (Fig. 6d).

\section{Primary production}

The mean PP value averaged over all stations showed a decreasing trend during the downwelling period. Later, when the surface water temperature started to increase, the mean PP increased and stayed at a higher level $\left(6-7 \mathrm{mg} \mathrm{C} \mathrm{m}^{-3} \mathrm{~h}^{-1}\right)$ until the end of the study (Fig. 7a). Spatial variation of the PP was quite low during the first three days, but deviations from the mean value varied in a large range (from -2.5 to 2.5 ) after the eddy had formed (Fig. $7 \mathrm{~b}$ ). The highest PP values were measured inside the observed eddy - at station A4 from 21 July

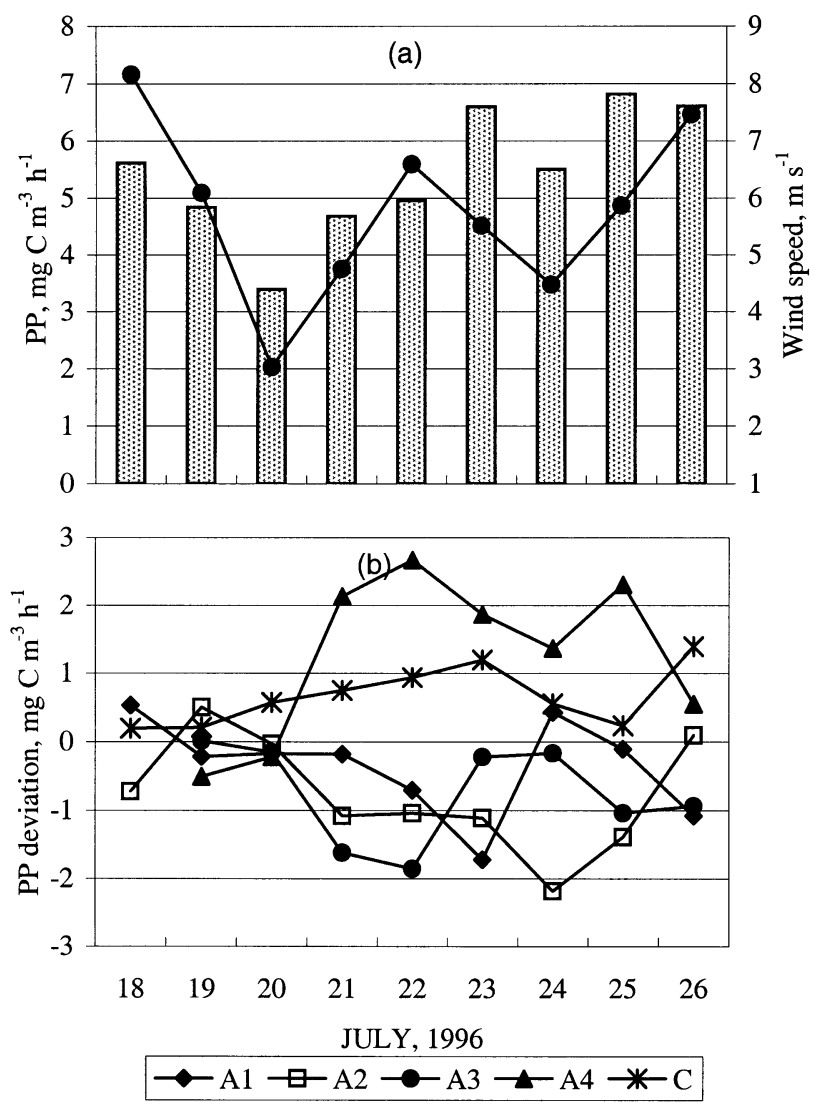

Fig. 7. Daily mean potential phytoplankton primary production (PP) (bars) and the preceding 24-h wind speed (line; a) and PP deviations (b) at the sampling stations on 18-26 July 1996. 
onward. Relatively low PP values were measured at station A2, which stayed outside the eddy and north-west directed jet influence area. Occasionally simultaneous low production values and low surface temperatures were observed at stations A3 and A1 close to the eddy periphery as well. The mean assimilation number (AN, $\mathrm{mg} \mathrm{C} \mathrm{h}{ }^{-1} \mathrm{mg} \mathrm{Chl} a^{-1}$ ) varied from 1.6 to 2.1 during the study except on 20 July $(\mathrm{AN}=0.9)$ and on 24 July $(\mathrm{AN}=1.1)$. The maximum $\mathrm{AN}(\mathrm{AN}=2.6)$ was obtained at station A4 on 22 July, showing the highest phytoplankton community activity inside the eddy just after its formation.

\section{Phytoplankton distribution and dynamics}

The dominant phytoplankton groups were cyanobacteria and dinoflagellates during the study. Among cyanobacteria the dominant species were Aphanizomenon flos-aquae and the Chroococcales group, and among dinoflagellates the bulk of the biomass was formed by Heterocapsa triquetra at all stations. At station A4 the dinoflagellates Dinophysis norvegica Claparède \& Lachmann and Gymnodinium spp. were abundant as well. At all stations, dinoflagellates dominated on the first day. The biomass of cyanobacteria started to increase on 21 July. At times A. flosaquae accounted for $95 \%$ the cyanobacterial biomass. The highest biomass values of A.flos-aquae were detected at station A2, which was located outside of the eddy area, and at station A1, which stayed out from the area influenced by the eddy after 22 July when the eddy moved a little to the north (Fig. 8). The biomass of
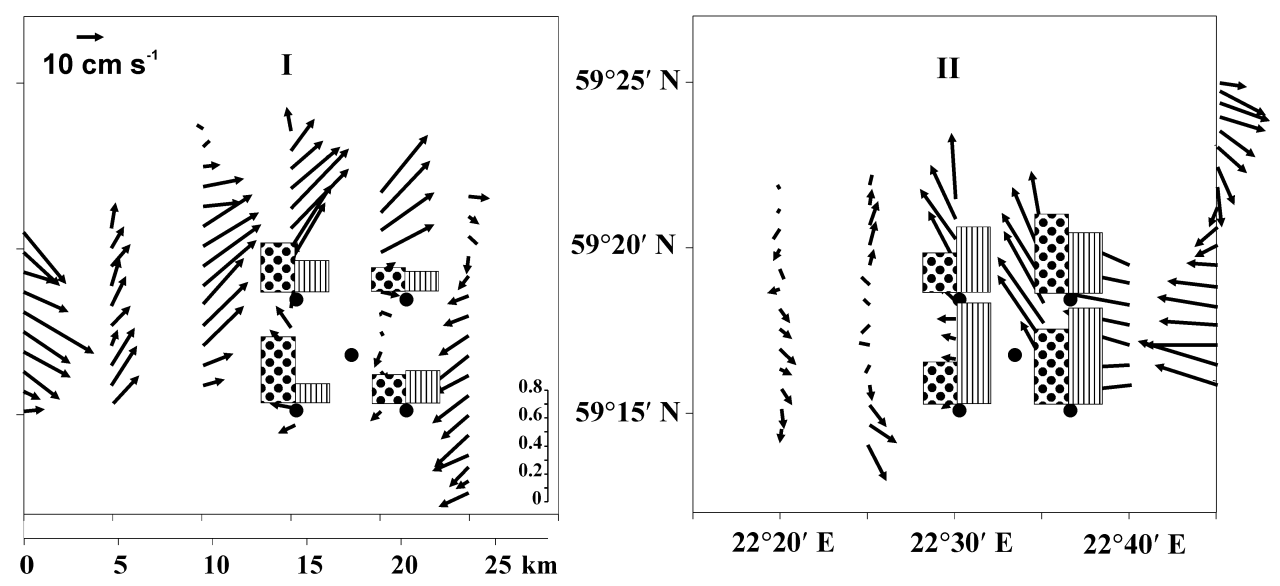

Fig. 8. Mean biomass ( $\mathrm{mg} \mathrm{L}^{-1}$, scale given in the left-hand panel) of Heterocapsa triquetra (dotted bars) and Aphanizomenon flos-aquae (striped bars) during the downwelling event (18-20 July; I) and after the eddy formation (21-26 July; II). ADCP velocities at 12-m depth on 18-19 and on 22-23 July are shown by stick-plots. 
potentially toxic Nodularia spumigena Mertens was close to the detection limit. Only a few segments of $N$. spumigena filaments were found in samples taken on 22-25 July.

At all stations except A4 the Aphanizomenon-Heterocapsa community structure changed after the eddy formation. During the first period Heterocapsa predominated and during the second period of the study Aphanizomenon prevailed. Heterocapsa continued to dominate only at station A4 during the whole study time. The phytoplankton community associated with the water mass inside the observed eddy was clearly different from the communities in the water masses that stayed at the periphery or outside the eddy influence area. At station A4 several species of small flagellates (Hemiselmis virescens Droop, Plagioselmis prolonga Butcher, Teleaulax amphioxeia (Conrad) Hill, Pyramimonas spp., Heterocapsa rotundata (Lohmann) Fott, Chrysochromulina spp.) were more abundant than at other stations (Fig. 9). During the first period of our study the importance of small dinoflagellates (H. rotundata) was the highest at stations A2 and A3. After the eddy had formed only station A4 kept this species biomass as high and even higher than it was before. The biomass of cryptomonads rose significantly at station A4 during the second period of the study. At other stations it remained nearly at the same level as during the downwelling event. The biomass of prymnesiophytes revealed no significant differences between stations during the presence of the mesoscale eddy.
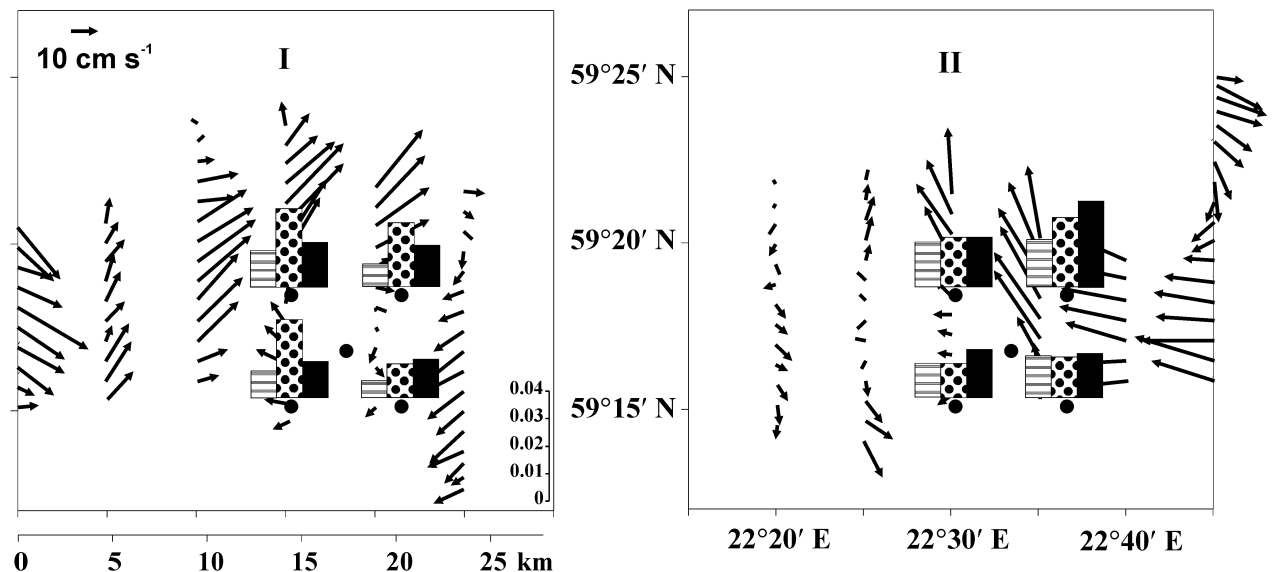

Fig. 9. Mean biomass ( $\mathrm{mg} \mathrm{L}^{-1}$, scale given in the left-hand panel) of prymnesiophytes (striped bars), small dinoflagellates (dotted bars), and cryptomonads (grey bars) during the downwelling event (18-20 July; I) and after the eddy formation (21-26 July; II). ADCP velociteis at 12-m depth on $18-19$ and on 22-23 July are shown by stick-plots. 


\section{Wind and primary productivity}

In order to study the response of the phytoplankton community to the changing wind forcing, the correlation between the daily mean wind speed and the potential production (measured at five stations once a day, mainly in the water sampled before noon) was estimated. The mean potential production did not correlate with the simultaneous wind speed in any of the stations but revealed some correlation with the preceding $24-\mathrm{h}$ mean wind speed $\left(r^{2}=0.32\right.$ at $p<0.15$; Fig. 7a). The potential production values taken at each station separately were (however, mostly insignificantly) positively correlated with the preceding 24-h mean wind speed estimate. The highest correlation $\left(r^{2}=0.44\right.$ at $\left.p<0.05\right)$ was detected at station A2, which was located outside the observed eddy during the whole study period.

\section{DISCUSSION}

In the marine environment phytoplankton production is controlled by the light and/or nutrients availability. These factors exert a direct effect on phytoplankton production. In summer only small amounts of available nutrients can be found in the surface waters of the open sea. Nutrients are supplied mainly through regeneration and vertical transport (Granéli et al., 1990). Thus, the vertical movements of water masses and the vertical mixing of the water column can play a major role in controlling the variability of nutrient concentrations (Delgadillo-Hinojosa, 1997) and can be fundamental in the formation of the structure and dynamics of the PP in the sea (Marra, 1980).

Enhanced levels of biological production have been attributed to the action of mesoscale eddies (Levy et al., 1998). During our study the highest values of PP in the surface layer were measured inside the observed eddy, while lower values were observed outside. Notably higher ANs were found at stations A4 and C during the first two days after the eddy had formed. After 20 July the salinity at station A4 was also considerably higher than at other stations (Fig. 2c). As both salt and nutrients are transported upwards from the deep saline layer these higher salinity values may indicate vertical fluxes inside the eddy. It should be pointed out that the salinity and PP deviations at station A4 were well correlated $\left(r^{2}=0.92\right.$, $p<0.005)$.

Several mechanisms have been suggested for the vertical transport of nutrients related to the mesoscale eddies. Nelson et al. (1989) found that the upwelling in the central part of an eddy significantly increases the time-integrated vertical transport of nutrients to the base of the euphotic zone and diminishes the amount of wind energy necessary to mix the nutrients upward into the surface layer. For a sub-surface anticyclonic eddy, which had a similar structure to the eddy mapped in the Gulf of Finland in the frames of the present study, the ageostrophic circulation 
was suggested as the main mechanism for the vertical transport of nutrients (Martin \& Richards, 2001). Another possible form of vertical transport within an isolated eddy, termed as "propagation flux" (McGillcuddy et al., 1995), is not realistic in our case as the eddy did not propagate significantly.

In our case the changes of PP inside the eddy did not correlate with the wind speed although some correlation between PP and wind was found outside the eddy. In addition, a higher variability of nutricline depth estimates was detected inside the eddy. Therefore we suggest that the relatively continuous vertical transport inside the eddy probably related to ageostrophic motions along the inclined isopycnals (Martin \& Richards, 2001) was responsible for the observed enhanced production. The daily vertical shift due to the ageostrophic motion along inclined isopycnal surfaces (having the characteristic scales of $10 \mathrm{~cm} \mathrm{~s}^{-1}$ for horizontal velocity and $15 \mathrm{~m}$ per $7-8 \mathrm{~km}$ for inclination) was roughly estimated to be $17 \mathrm{~m}$.

The wind-induced vertical mixing could be expected to be a possible mechanism for bringing nutrient pulses up to the UML at least outside the eddy. It was confirmed earlier (Marra et al., 1990; Kiørboe, 1993; Kononen et al., 1996) that short-term stronger winds induce mixing and cause vertical fluxes of nutrients across the pycnocline into the euphotic zone. As the organisms cannot immediately track the environmental changes, specific time lags separating physical disturbances and their effects on the biological system should exist. This has been confirmed in our study by estimates of correlation between the preceding 24-h mean wind speed and the mean PP $\left(r^{2}=0.44\right.$ at $p<0.05$; Fig. 7a $)$. The correlation estimate is considered good because the PP series was masked by the tendency to increase with the rising temperature during the study period. On the other hand, considering the strong stratification and the depth of the nutricline, the wind seems to be too weak $\left(2-8 \mathrm{~m} \mathrm{~s}^{-1}\right)$ to transfer the nutrients into the upper mixed layer. However, there had to be mechanisms that favoured the phytoplankton production enhancement after stronger wind impulses. Thus another explanation of the observed relationship has to be found.

Nutrient variability is frequently associated with changes in the adaptive advantages among populations with different nutrient requirements (Tilzer, 1989). It is often assumed that the nutrient uptake rate in phytoplankters depends on the cell surface area and that therefore the nutrient uptake is most efficient in small cells due to their higher specific surface area (Kiørboe, 1993). The importance of the $<20-\mu \mathrm{m}$ size fraction was relatively high inside the eddy and low outside, while the biomass of the larger size fraction was relatively high in the eddy periphery and outside its influence area. One hypothesis that can explain the dominance of small algae inside the eddy area is continuous but relatively low inputs of nutrients. In these conditions only small algae will be responsible for the PP because they are superior competitors for nutrients. The above-mentioned good correlation between salinity and PP deviations may support our hypothesis that inside the eddy the rise in the biomass was due to the upward nutrient fluxes (even if these were small) and outside the eddy the changes in the biomass were mainly caused by the horizontal advection. 
During the summer period a conspicuous feature of the phytoplankton in the Baltic Sea is the mass occurrence of cyanobacterial blooms (Kahru et al., 1994). The initiation of filamentous cyanobacteria blooms in the Baltic Sea is connected with the nutrient limitation and competition (Niemistö et al., 1989; Granéli et al., 1990). Low DIN:DIP ratios in the Baltic Sea (Kononen \& Leppänen, 1997) and the ability to fix molecular nitrogen (Niemi, 1979; Howarth et al., 1988) gives the filamentous cyanobacteria an advantage compared to other species in summertime (Sellner, 1997). As the weather was cold during our study summer and the water temperature was low, no large bloom was formed. Nevertheless, a clear distribution pattern of cyanobacteria dependent on the occurrence of hydrodynamical processes was distinguished. The highest biomass values of $\mathrm{A}$. flosaquae were detected during our study outside of the eddy influence area - at stations A2 and A1 after 22 July when the eddy moved to the north and station A1 stayed out of the eddy area (Fig. 8). Inside the eddy the highest abundances of H. triquetra were observed. The spatio-temporal distribution of Aphanizomenon and Heterocapsa is described in more detail by Kononen et al. (1999).

\section{CONCLUSIONS}

Despite the high variability of biological parameters in the study area due to the horizontal advection, clear indications of hydrodynamic control of phytoplankton productivity and species composition pattern in the upper layer were observed. The largest values of the primary production in regard to the daily mean values were observed in the water mass trapped inside the anticyclonic eddy. A significant correlation between the wind speed of the preceding day and the phytoplankton primary production was found in the area not influenced by the observed eddy. The flagellates abundance was the highest inside the eddy, while the proportion of cyanobacteria in the plankton community was the highest outside. Therefore, vertical ageostrophic motions associated with a mesoscale eddy and occasional events of mixing on the background of low DIN and DIP concentrations seem to be favourable for various groups of phytoplankton.

\section{ACKNOWLEDGEMENTS}

This work was financially supported by the Estonian Science Foundation (grant No. 2195) and Maj and Tor Nessling Foundation. Our thanks are due to the crews of the research vessels Reet and Aranda. The authors acknowledge the valuable help of Jaan Laanemets and Juss Pavelson. We are grateful to Aleksander Toompuu for language revisions. 


\section{REFERENCES}

Delgadillo-Hinojosa, F., Gaxiola-Castro, G., Segovia-Zavala, J. A., Muñoz-Barbosa, A. \& OrozcoBorbón, M. V. 1997. The effect of vertical mixing on primary production in a bay of the Gulf of California. Estuarine Coastal Shelf Sci., 45, 135-148.

Edler, L. (ed.) 1979. Recommendations on mehods for marine biological studies in the Baltic Sea. Phytoplankton and chlorophyll. Baltic Mar. Biol. Publ., 5.

Franks, P. J. S. 1992. Sink or swim: accumulation of biomass at fronts. Mar. Ecol. Prog. Ser., 82, $1-12$.

Franks, P. J. S. 1997. Spatial patterns in dense algal blooms. Limnol. Oceanogr., 42, 1297-1305.

Granéli, E., Wallström, K., Larsson, U., Granéli, W. \& Elmgren, R. 1990. Nutrient limitation of primary production in the Baltic Sea area. Ambio, 19, 142-151.

HELCOM 1988a. Guidelines for the Baltic Monitoring Programme for the third stage. Baltic Sea Envir. Proc., 27B.

HELCOM 1988b. Guidelines for the Baltic Monitoring Programme for the third stage. Baltic Sea Envir. Proc., 27D.

Howarth, R. W., Marino, R. \& Cole, J. J. 1988. Nitrogen fixation in freshwater, estuarine, and marine ecosystems. 2. Biochemical controls. Limnol. Oceanogr., 33, 688-701.

Kahru, M., Horstmann, U. \& Rud, O. 1994. Satellite detection of increased cyanobacterial blooms in the Baltic Sea: natural fluctuation or ecosystem change? Ambio, 23, 469-472.

Kiørboe, T. 1993. Turbulence, phytoplankton cell size, and the structure of pelagic food webs. $A d v$. Mar. Biol., 29, 1-72.

Kononen, K. \& Leppänen, J.-M. 1997. Patchiness, scales and controlling mechanisms of cyanobacterial blooms in the Baltic Sea: application of a multiscale research stradegy. In Monitoring Algal Blooms: New Techniques for Detecting Large-Scale Environmental Change (Kahru, M. \& Brown, C. W., eds.), pp. 63-84. Springer-Verlag, Berlin, Heidelberg, New York.

Kononen, K., Forsskåhl, M., Huttunen, M., Sandell, M. \& Viljamaa, H. 1983. Practical problems encountered in phytoplankton cell volume calculations using the BMB recommendations. Limnologica, 15, 605-614.

Kononen, K., Kuparinen, J., Mäkela, K., Laanemets, J., Pavelson, J. \& Nõmmann, S. 1996. Initiation of cyanobacterial blooms in a frontal region at the entrance of the Gulf of Finland, Baltic Sea. Limnol. Oceanogr., 41, 98-112.

Kononen, K., Hällfors, S., Kokkonen, M., Kuosa, H., Laanemets, J., Pavelson, J. \& Autio, R. 1998. Development of a subsurface chlorophyll maximum at the entrance to the Gulf of Finland, Baltic Sea. Limnol. Oceanogr., 43, 1089-1106.

Kononen, K., Huttunen, M., Kanoshina, I., Laanemets, J., Moisander, P. \& Pavelson, J. 1999. Spatial and temporal variability of a dinoflagellate-cyanobacterium community under a complex hydrodynamical influence: a case study at the entrance to the Gulf of Finland. Mar. Ecol. Prog. Ser., 186, 43-57.

Laanemets, J., Pavelson, J., Lips, U. \& Kononen, K. 2005. Downwelling related mesoscale motions at the entrance to the Gulf of Finland: observations and diagnosis. Oceanol. Hydrobiol. Stud., in press.

Levy, M., Memery, L. \& Madec, G. 1998. The onset of a bloom after deep winter convection in the northwestern Mediterranean Sea: mesoscale process study with a primitive equation model. J. Mar. Syst., 16, 7-21.

Marra, J. 1980. Vertical mixing and primary production. In Primary Productivity in the Sea (Falkowsky, P. G., ed.), pp. 121-137. Plenum Publ. Corp., New York.

Marra, J., Bidigare, R. R. \& Dickey, T. D. 1990. Nutrients and mixing, chlorophyll and phytoplankton growth. Deep-Sea Res., 37, 127-143.

Martin, A. P. \& Richards, K. J. 2001. Mechanisms for vertical nutrient transport within a North Atlantic mesoscale eddy. Deep-Sea Res., II 48, 757-773. 
Martin, A. P. \& Pondaven, P. 2003. On estimates for the vertical nitrate flux due to eddy pumping. J. Geophys. Res., 108(C11), 3359-3368.

McGillcuddy, D. J., Jr. \& Robinson, A. R. 1997. Eddy-induced nutrient supply and new production in the Sargasso Sea. Deep-Sea Res., 44, 1427-1450.

McGillcuddy, D. J., Robinson, A. R. \& McCarthy, J. J. 1995. Coupled physical and biological modelling of the spring bloom in the North Atlantic (II): three dimensional bloom and postbloom processes. Deep-Sea Res., I 42, 1359-1398.

McGillcuddy, D. J., Jr., Anderson, L. A., Doney, S. C. \& Maltrud, M. E. 2003. Eddy-driven sources and sinks of nutrients in the upper ocean: results from a $0.1^{\circ}$ resolution model of the North Atlantic. Global Biochem. Cycles, 17, 1035-1054.

Moisander, P., Rantajärvi, E., Huttunen, M. \& Kononen, K. 1997. Phytoplankton community in relation to salinity fronts at the entrance to the Gulf of Finland, Baltic Sea. Ophelia, 36, 187-203.

Nelson, D. M., McCarthy, J. J., Joyce, T. M. \& Ducklow, H. W. 1989. Enhanced near-surface nutrient availability and new production resulting from the frictional decay of a Gulf Stream warm-core ring. Deep-Sea Res., 36, 705-714.

Nielsen, G. A. \& Bresta, A.-M. 1984. Guidelines for the measurement of phytoplankton primary production. Baltic Mar. Biol. Publ., 1.

Niemi, Å. 1979. Blue-green algal blooms and N:P ratio in the Baltic Sea. Acta Bot. Fenn., 110, 57 61.

Niemistö, L., Rinne, I., Melvasalo, T. \& Niemi, Å. 1989. Blue-green algae and their nitrogen fixation in the Baltic Sea in 1980, 1982 and 1984. Meri, 17, 1-59.

Oschlies, A. 2002. Can eddies make ocean deserts bloom? Global Biochem. Cycles, 16, 1106-1116.

Pavelson, J., Laanemets, J., Kononen, K. \& Nõmmann, S. 1997. Quasi-permanent density front at the entrance to the Gulf of Finland: response to wind forcing. Cont. Shelf Res., 17, 253-265.

Pavelson, J., Kononen, K. \& Laanemets, J. 1999. Chlorophyll distribution patchiness caused by hydrodynamical processes: a case study in the Baltic Sea. ICES J. Mar. Sci., 56, Suppl., 87-99.

Sellner, K. G. 1997. Physiology, ecology, and toxic properties of marine cyanobacteria blooms. Limnol. Oceanogr., 42, 1089-1104.

Talpsepp, L., Nõges, T., Raid, T. \& Kõuts, T. 1994. Hydrophysical and hydrobiological processes in the Gulf of Finland in summer 1987: characterization and relationship. Cont. Shelf Res., 14, 749-763.

Tilzer, M. M. 1989. Distinction between light mediated and light independent variation in phytoplankton production rates. Hydrobiologia, 173, 135-140.

Utermöhl, H. 1958. Zur Vervollkommnung der quantitativen Phytoplanktonmetodic. Mitt. Int. Ver. Limnol., 9, 1-38.

\title{
Hüdrodünaamiliste protsesside mõju fütoplanktoni algproduktsioonile ja liigilisele koosseisule Soome lahe suudmealal 1996. a juulis
}

\author{
Inga Lips, Urmas Lips, Kaisa Kononen ja Andres Jaanus
}

1996. a juulis korraldati Soome lahe suudmealal 10-päevane interdistsiplinaarne eksperiment, mille eesmärgiks oli uurida hilissuvise fütoplanktoni õitsengu kujunemist ning seda kontrollivaid mehhanisme. Uurimisperioodil jälgiti antud merealal selgelt eristuvaid füüsikalisi nähtusi - langevhoovust, nõlvaäärseid 
jugahoovusi ja mesomastaapset antitsüklonaalset pöörist. Jugahoovuste ja pöörisega seotud suhteliselt suured voolukiirused (kuni $35 \mathrm{~cm} \mathrm{~s}^{-1}$ ) tingisid erinevate veemasside liikumise läbi uurimisala, mis põhjustas bioloogiliste parameetrite märkimisväärse muutlikkuse. Pöörise teke peegeldus fütoplanktoni produktiivsuse ja liigilise koosseisu ruumilises laigulisuses ülemises veekihis. Kõrgeim algproduktsiooni väärtus mõõdeti antitsüklonaalsesse pöörisesse "lõksu jäänud" veemassis. Flagellaatide biomass oli kõrgeim pöörise sees, samal ajal kui sinivetikate osakaal planktoni koosluses oli suurim pöörisest väljaspool. Teostatud analüüsi põhjal võib teha järelduse, et mesomastaapse pöörisega seotud vertikaalsed liikumised ja juhuslikud tuulest tingitud segunemise sündmused madala anorgaanilise lämmastiku ja fosfori sisalduse taustal olid soodsad erinevatele fütoplanktoni rühmadele. 